\title{
EARLY TRANSFORMATION AND ENLIGHTENMENT OF THE CONSTRUCTION AND MANAGEMENT OF THE BRITISH CONCESSION IN MODERN EAST ASIA RESEARCH ON 1866 LAND REGULATIONS OF THE BRITISH CONCESSION OF TIENTSIN
}

\author{
Sun Shuting, Aoki Nobuo \\ School of Architecture, Tianjin University
}

KEY WORDS: British Concession, Settlement, Tianjin, Land Regulation, Urban Construction Management, East Asian city modernization.

\begin{abstract}
:
The systematic development of British Concession in the 19th century had a profound impact on the development of cities in the history of modernization in East Asia. To find out the relevance of the urban management system of the British concession and the process of urban modernization between different cities in East Asia, this paper combs the development process of land allocation and urban management in the early British concession by using the land regulation. It focuses on the specific case of the 1866 land regulation promulgated by the British concession in Tianjin from the perspective of colonialism and the construction and management system of the East Asian British concession. It analyses the historical background and influence, then further explores the reasons for its promulgation. This finding can fill part of the vacancy in the history of urban development and play an important role in the development of contemporary urban construction in East Asia as reflection and reference.
\end{abstract}

\section{INTRODUCTION}

China is in a stage of accelerating urbanization and expanding the scale of cities. However, in the urban management model, there are still problems such as imperfect law formulation, low level of democratization of urban management, and ineffective planning and supervision system (Shengcai, S., Shuai H., 2020). In the 19th century, the emergence of the "concession" made the planning and management of the Chinese traditional to modern western planning ideas. In urban planning, construction and control are its two major starting points, and control is the main task of the planning authority (Ying Z., 2014). Studying the construction laws and regulations of the concession has some enlightenment for the current construction management.

In the 19th century, European powers opened the East Asian market through trade and indirectly promoted the modernization of East Asian cities. Westerners established colonies, concessions, settlements, etc. in East Asian countries through mission, trade, and diplomacy ${ }^{(1)}$. Introduce modern city

(1) Chapters 9 and 11 of Fei Chengkang's "History of Chinese Concessions" divide the land occupied by foreigners into concessions, leased land, summer resorts, foreign residence areas, shopping malls, etc.; It said the difference between the concession and other types is whether there are foreigners Infringement of local administrative power; By the way, word "settlement" as English generally refers to various areas where foreigners reside in concessions. Regarding the residences and concessions in China and Japan, Yuzo Kato proposed the same name in English as settlement. In China, it is called concession; and in Japan, it is called settlements for foreigners; and analyzed its political and economic differences. Both Chinese concessions and Japanese foreigners' settlement have infringements on local administrative rights by foreigners, and corresponding land regulations have been promulgated. In addition, the relevance of Chinese characters within Asia reflects the management system, advanced municipal construction, and western culture to East Asia. Britain. As the sun never sets Empire at that time, England was the country with the earliest, largest number, longest duration, and greatest influence in concession. It took the lead in establishing a series of concession systems (Chengkang F., 1991). The British Concession is the focus of the study on the modernization of East Asian cities. The "Land Regulations", which is the foundation of concession governance, contains relevant rules for urban planning and construction. It is the institutional basis for the modernization of East Asian cities.

\section{LITERATURE REVIEW}

China and foreign research on the "Land Regulations" of the concession has achieved certain results ${ }^{(2)}$. However, due to the limitations of language and historical materials, domestic research is mainly centered on Shanghai, and there is less research on other China cities. At the same time, the lack of an international macro perspective also led to the inability to

Japanese call for Chinese concessions. When Japan was preparing to open up concessions in China, it referred to Chinese concessions as "settlement" and later mixed-use, so the Japanese "settlement" is "concession."

(2) Xiang Yang's "Observations and Reflections on the Study of Land Regulations in Shanghai Concessions" summarizes the research overview of Shanghai's land regulations; Geng keyan's "Space, System and Society: Modern Tianjin British Concession Studies (1860-1945)" etc. only focus on Tianjin's land regulations. A large number of Japanese scholars (such as Fujimori Nobubu, Muramatsu, Nishizawa Yasuhiko, Murata Akihisa, Izumada Hero, Osato Hiroshiaki, Zhao Shichen, etc.) have rich research results on the ports of China, Japan, and North Korea. Still, there are not many mergers of land regulations. The exception focuses on the loss of Japanese power in the land regulations, such as " A Survey of Yokohama Residence in 1860 ". 
clearly outline the evolution of the "Land Regulations" in the British Concession in East Asia. By combing through relevant historical archives, this article puts Tianjin's 1866 "Land Regulations" under the historical background of British colonization in East Asia, explores the reasons for its formulation, discusses its particularity. Then further sorts out the process of colonial modernization in the British concessions in East Asia, and the development of the urban management contexts.

\section{DEVELOPMENT OF THE "LAND REGULATIONS" IN THE CONCESSION}

\subsection{British East Asian development model in the early concession}

In the early days of the British trade with modern East Asia, it was established Concessions and settlements in Shanghai (1843), Amoy (1852), Nagasaki (1858), Yokohama (Kanagawa) (1858), Canton (1859) and Tianjin (1860) (Figure 1). Concessions, as a special form of colonization formed in East Asia, were insignificant in the formation of the British Empire. Although with the development of the concession, the British began joint activities with the Chinese in the concession. However, because the British who came to the concession initially were mainly the British who traded overseas, the establishment of the concession was also based on white colonies. The settlement of the colonial policy had an impact on the construction and management of the concession. Under the influence of the new concept of Empire, the British people generally believe that the overseas concessions have imposed a burden on the British economy and hope to obtain the autonomy of the British concessions as soon as possible (Benying Z., 2009).

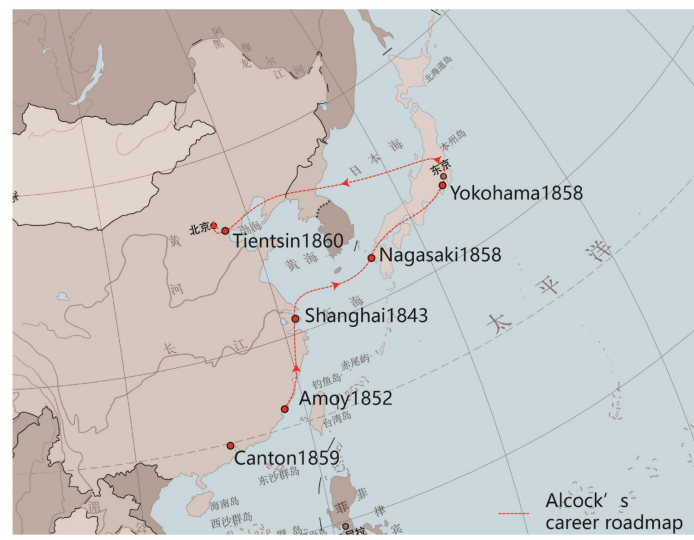

Figure 1. The distribution of British concessions and settlements in early modern East Asia (1840-1860)

\section{2 "Land Regulations" Establishment and Development}

In the $1860 \mathrm{~s}$, The emergence of "Little England"(3) further promoted the colonial reform and self-government movement (Bentao W., 2009). The concession as a "state within a country" corresponds to the establishment of the Municipal Council and the formation of Resident self-government system in the "Land Regulations". The colonists fought fiercely for the management and autonomy of the land. It created neither the "gratis possession" that was completely equivalent to the colony, nor the "civil rent" among Asian natives; instead, it produced a land lease method and land management system similar to that between countries--"Land Regulations". Concession planning is the process of realizing the redistribution of land and making it legal. The regulation defines the way of renting land by tenants, the main body of urban planning, the source of funds for concession construction, and urban public health control, etc., in order to achieve the purpose of construction and management of concessions, similar to today's " Act of urban planning."

Each formulation or revision of these "Land Regulations" does not start from scratch, but is based on the social conditions and management experience at that time (Table 1). "Land Regulations" revision of the course is the British continued to strengthen its self-governance rights and improve the process of concession of public infrastructure, but also its constantly adapt to changes in the process of modernization of the historical process of urban development in East Asia.

\begin{tabular}{|c|c|c|c|c|}
\hline Years & Name & $\begin{array}{l}\text { British } \\
\text { related } \\
\text { makers }\end{array}$ & $\begin{array}{l}\text { Make or } \\
\text { modify the } \\
\text { background }\end{array}$ & Features \\
\hline 1845 & $\begin{array}{l}\text { Shanghai } \\
\text { British } \\
\text { Concession } \\
\text { "Land } \\
\text { Regulations" }\end{array}$ & $\begin{array}{l}\text { British } \\
\text { Consul } \\
\text { in } \\
\text { Shangh } \\
\text { ai } \\
\text { Sir } \\
\text { George } \\
\text { Balfour }\end{array}$ & $\begin{array}{l}\text { The early } \\
\text { establishme } \\
\text { nt of the } \\
\text { British } \\
\text { Concession } \\
\text { in } \\
\text { Shanghai }\end{array}$ & $\begin{array}{l}\text { Emphasis on } \\
\text { land lease } \\
\text { methods, } \\
\text { public } \\
\text { infrastructure } \\
\text { construction } \\
\text { based on the } \\
\text { road planning }\end{array}$ \\
\hline 1854 & $\begin{array}{l}\text { Shanghai } \\
\text { Public } \\
\text { Concession } \\
\text { "Shanghai } \\
\text { Anglo- } \\
\text { French- } \\
\text { American } \\
\text { Concession } \\
\text { Land Lease } \\
\text { Regulations" }\end{array}$ & $\begin{array}{l}\text { British } \\
\text { Consul } \\
\text { in } \\
\text { Shangh } \\
\text { ai } \\
\text { Sir } \\
\text { Rutherf } \\
\text { ord } \\
\text { Alcock }\end{array}$ & $\begin{array}{l}\text { The public } \\
\text { concession } \\
\text { was } \\
\text { established, } \\
\text { and a large } \\
\text { number of } \\
\text { Chinese } \\
\text { people } \\
\text { poured into } \\
\text { the } \\
\text { concession }\end{array}$ & $\begin{array}{l}\text { Increase the } \\
\text { municipal } \\
\text { council treaty } \\
\text { to give taxation } \\
\text { powers }\end{array}$ \\
\hline 1860 & $\begin{array}{l}\text { Yokohama } \\
\text { Foreign } \\
\text { Settlement } \\
\text { "Land }\end{array}$ & $\begin{array}{l}\text { Consul } \\
\text { Genera } \\
1 \quad \text { in } \\
\text { Japan }\end{array}$ & $\begin{array}{l}\text { Establishm } \\
\text { ent of the } \\
\text { Yokohama } \\
\text { Foreign }\end{array}$ & $\begin{array}{l}\text { The Japanese } \\
\text { government is } \\
\text { responsible for } \\
\text { municipal }\end{array}$ \\
\hline
\end{tabular}

(3) With the completion of the British Industrial Revolution in the 19th century and the abolition of the "Corn Law" in 1846, Britain began to grant autonomy to the colonies under the influence of free trades, and a new concept of the empire gradually formed. Britain's strategy for East Asia has also begun to change. The Liberal Party, represented by the Manchester School, advocates a basic foreign policy not to use military power or political control but to use cheap and abundant commodities as "weapons" to expand overseas markets. See (Masuda T., 1980) for details. 


\begin{tabular}{|c|c|c|c|c|}
\hline & $\begin{array}{l}\text { Regulations } \\
\text { port of } \\
\text { Yokohama" }\end{array}$ & $\begin{array}{l}\text { Sir } \\
\text { Rutherf } \\
\text { ord } \\
\text { Alcock }\end{array}$ & Settlement & $\begin{array}{l}\text { construction, } \\
\text { and at the same } \\
\text { time, it forms } \\
\text { an autonomous } \\
\text { system of } \\
\text { residents with } \\
\text { police powers } \\
\text { and taxation } \\
\text { powers in their } \\
\text { residences. }\end{array}$ \\
\hline 1860 & $\begin{array}{l}\text { Nagasaki } \\
\text { Foreign } \\
\text { Settlement } \\
\text { "Land } \\
\text { Regulations } \\
\text { port of } \\
\text { Nagasaki " }\end{array}$ & $\begin{array}{l}\text { Consul } \\
\text { Genera } \\
1 \quad \text { in } \\
\text { Japan } \\
\text { Sir } \\
\text { Rutherf } \\
\text { ord } \\
\text { Alcock }\end{array}$ & $\begin{array}{l}\text { Establishm } \\
\text { ent of the } \\
\text { Nagasaki } \\
\text { Foreign } \\
\text { Settlement }\end{array}$ & $\begin{array}{l}\text { Almost the } \\
\text { same as the } \\
\text { Yokohama } \\
\text { Land } \\
\text { Regulations }\end{array}$ \\
\hline 1864 & $\begin{array}{l}\text { Yokohama } \\
\text { Foreign } \\
\text { Residency } \\
\text { "Memorandu } \\
\text { m of port of } \\
\text { Yokohama " }\end{array}$ & $\begin{array}{l}\text { Consul } \\
\text { Genera } \\
1 \quad \text { in } \\
\text { Japan } \\
\text { Sir } \\
\text { Rutherf } \\
\text { ord } \\
\text { Alcock }\end{array}$ & $\begin{array}{l}\text { Foreign } \\
\text { groups are } \\
\text { dissatisfied } \\
\text { with the } \\
\text { constructio } \\
\mathrm{n} \text { of the } \\
\text { shogunate' } \\
\mathrm{s} \\
\text { infrastructu } \\
\text { re, and } \\
\text { demand } \\
\text { increased } \\
\text { autonomy. }\end{array}$ & $\begin{array}{l}\text { The Ministry } \\
\text { of Construction } \\
\text { of } \\
\text { infrastructure } \\
\text { concession } \\
\text { points right to } \\
\text { the residence } \\
\text { militia, also } \\
\text { asked the } \\
\text { shogunate } \\
\text { recognition of } \\
\text { its right to self- } \\
\text { government } \\
\text { administration. }\end{array}$ \\
\hline 1866 & $\begin{array}{l}\text { Tianjin } \\
\text { British } \\
\text { Concession } \\
\text { "Tianjin } \\
\text { Land } \\
\text { Regulations } \\
\text { and General } \\
\text { Regulations" }\end{array}$ & $\begin{array}{l}\text { Ministe } \\
\mathrm{r} \quad \text { in } \\
\text { China } \\
\text { Sir } \\
\text { Rutherf } \\
\text { ord } \\
\text { Alcock }\end{array}$ & $\begin{array}{l}\text { Amendmen } \\
\text { ts to the } \\
\text { regulations } \\
\text { governing } \\
\text { British } \\
\text { concession } \\
\mathrm{s} \text { and } \\
\text { adjustment } \\
\mathrm{s} \text { to the } \\
\text { British } \\
\text { China } \\
\text { policy }\end{array}$ & $\begin{array}{l}\text { According to } \\
\text { the first } \\
\text { national rent } \\
\text { recognized by } \\
\text { the treaty, the } \\
\text { detailed rules } \\
\text { of the British } \\
\text { Concession } \\
\text { Autonomous } \\
\text { System were } \\
\text { formed. }\end{array}$ \\
\hline 1869 & $\begin{array}{l}\text { Land } \\
\text { Regulations } \\
\text { and Bye- } \\
\text { Laws for the } \\
\text { Foreign } \\
\text { Settlements } \\
\text { of Shanghai } \\
\text { North of the } \\
\text { Yang-King- } \\
\text { Pang. }\end{array}$ & $\begin{array}{l}\text { Ministe } \\
r \quad \text { in } \\
\text { China } \\
\text { Sir } \\
\text { Rutherf } \\
\text { ord } \\
\text { Alcock }\end{array}$ & $\begin{array}{l}\text { The "Free } \\
\text { City" plan } \\
\text { failed, and } \\
\text { the British } \\
\text { tried to } \\
\text { gain more } \\
\text { city power }\end{array}$ & $\begin{array}{l}\text { Detailed urban } \\
\text { construction } \\
\text { regulations } \\
\text { were formed, } \\
\text { and the } \\
\text { concession } \\
\text { autonomy } \\
\text { system was } \\
\text { further } \\
\text { improved. }\end{array}$ \\
\hline
\end{tabular}

Table 1. Early "Land Regulations" in the British Concession of East Asia.

Before the establishment of the "Land Regulations", the foreigners who came to the concessions or settlements were mainly large foreign firms. In 1844 Dent Matheson was the first in the Huangpu River shore to lease 13 acres of land, followed by Jardine Matheson. After these foreign banks leased the land, they built warehouses, offices, factories, etc. on their respective plots, forming the initial concession port space (Bund) ${ }^{(4)}$. Initially, the "Land Regulations" was established to solve the problem of chaotic land lease, and gradually formed a "perpetual lease system"(5). With the development of the concession, the content of urban management gradually appeared in the land regulation, which gradually clarified the main body of urban planning and the principle of public participation. Such as the 1845 Shanghai the first "Land Regulations" of the British concession of urban control is mainly reflected in the construction space control ${ }^{(6)}$, Relevant road planning (paragraphs2,3 and 4), land function division ${ }^{(7)}$. In addition to extending the construction space control part (paragraphs 1 and 6) of the land regulation of 1845 (paragraphs 1 and 6), the Shanghai "Land Regulations" of 1854 emphasized the construction of municipal public infrastructure with roads as the core (paragraph 5). Provisions on building materials and constructions (paragraph 9). In addition, in accordance with the tenth "selection of three or more people", the committee on Roads and Jetties in the concession formally withdrew from the historical stage. They replaced it with a formal administrative agency- The Municipal Council, which has since determined the main body of urban construction management and control. This is the institutional basis for the zoning of public infrastructure and urban functional layout in the concession.

\section{AVAILABLE ARCHIVES AND SOURCES}

This project requires a variety of archives. (1) The first is to sort through the policy archives in the British Parliamentary Papers to understand British colonial policy towards China and Japan, which are mainly held in government reports and parliamentary minutes in the British National Archives, the School of Oriental and African Studies at the University of London and the British Library. Among them are the British Parliamentary Papers published and collated by the British National Archives. 2 The second is the collation of the drawings in the archives, including the relevant technical drawings in the British National Archives, as well as the History of Yokohama City collated in the Yokohama Kaikou Museum and the Nagasaki Prefectural Nagasaki Library, and the Documents on Foreign Relations at the End of the Shogunate published by the Historical Compilation Institute of the University of Tokyo The Ministry of Foreign Affairs of Japan A Chronology of Japanese Diplomacy with Major Instruments, compiled by the Ministry of Foreign Affairs of Japan, and The Complete List of Records of the Ministry of Foreign Affairs in the Collection of the Diplomatic History Museum, Pre-War Period, Volume I, Meiji and Taisho Chapters, Diplomatic Instruments of Japan, etc. (3) Further required are the diplomatic documents of land charters and government officials from various places, which are

(4) The plan adopts basic rules, uniform narrow and deep plot division method, and a geometric road grid system. The narrow and deep plot shape of the waterfront is conducive to the maximum efficient use of the river dam Bund and street space, which is convenient for improving the efficiency of lease and use.

(5) Take Shanghai as an example. After obtaining the Dao Deed issued by Shanghai Daotai, the merchant owns the ownership of the real estate, and can use Dao deed as the basis for free real estate transfer and sale.

(6) Including the determination of the boundary of the concession (paragraph 1) and the definition of the construction land of each tenant (paragraph 6)

(7) Roughly delineate residential area, commercial area, public land, municipal construction land, and storage land (paragraphs 10, 16, 17, 18) 
concentrated in the reports of various consuls and consuls in Japan recorded in British documents on foreign affairs : reports and papers from the Foreign Office. This section also contains some of the materials of the foreign offices in the Harvard University Library, including a list of foreign offices of various eras and the Foreign Office in Japan, "The Complete 48 Rolls of Foreigners in Japan at the End of the Meiji Period". (5) Miscellaneous documents on imperial residences in various parts of China, etc., in the collection of the Foreign Affairs Historical Museum, Ministry of Foreign Affairs of Japan. (6) The Land Register of the British Concessions (F.O. 421) in the British National Archives; Miscellaneous (F.O. 354) of the instruments transferred to the British Embassy in Japan concerning international arbitration awards on property taxation.

\section{METHODOLOGY}

5.1 Historical research in the context of urban economics and urban sociology.

Through the study of archives and rare British and Japanese historical sources, as well as a review of previous research, the scope and objectives of the study will be established. Identify the specific provisions of early land charters, collect correspondence from key figures, the similarities and differences in the land development activities of British bourgeoisie in the context of the different charters, and explore their impact on urban space.

\subsection{Collation of historical maps and plot data.}

The collection of maps of the settlement in historical sources and archives from different periods, the collation of basic information on the land parcels of the Sino-Japanese and British concessions and settlements in various eras, and the sorting out of the process of land management by the concession authorities through the Land Register and the Directory, etc.

\subsection{Comparative analysis under the British Concession} system

To compare and contrast the similarities and differences in the content of the land charters enacted in different periods, to compare and analyse the reasons for these similarities and differences, and to sort out the historical lineage of the development of the land charters of the British Concessions and the Residency in early East Asia from a holistic perspective.

\section{RESULTS}

\subsection{The emergence of the Tianjin "land regulation" and its historical position}

Tianjin British concession "Land Regulations" in 1866 served as a link between the past and future of the early development of the East Asia Department in the British Concession. As the largest British concession in East Asia, the establishment of Tianjin British Concession has two meanings in the history of modern Chinese urban construction. One is the first time that the United Kingdom has leased land in the form of "state rent" in the East Asian concession in the form of a treaty permit, allowing the United Kingdom to realize the overall plan of the concession (the Gordon Plan in 1861), which determines the basic urban spatial form of the concession. The second is it is the first time in the regulations to accept the rights of the committee of land renters and Municipal Council, which is the starting point of concession self-government legalization. Due to the impact of taxation on its municipal construction, Tianjin British Concession has gradually formed a concession development and construction model dominated by wealthy
British businessmen. This model has a huge impact on the construction of urban space and municipal infrastructure in the concession. After the establishment of the "Land Regulations" in Tianjin in 1866, the "Land Regulations" and municipal regulations of the British Concession in East Asia began to be gradually legalized, and various institutional systems were continuously improved. In addition, other countries' concessions in Tianjin basically borrowed from the management system of the British concession in Tianjin and promoted the modernization of Tianjin.

\subsection{The specific influence to the urban construction} management mode of Tianjin 1866 "land regulations"

The 1866 "Land Regulations" of the British Concession in Tianjin is the full name "1866 Land Regulations of the British Concession of Tientsin and General Regulations. for the Tientsin Consular District". Including a total of 23, covering the scope of the concession, qualification of land renters, the committee of land renters, executive committee or council and the electoral vote, donate terms of taxes and licenses, and so on (Keyan G., 2014). The regulations on land lease methods and construction management methods have directly affected the urban planning of the British concessions. They have undergone major changes compared with the previous "Land Regulations". 
6.2.1 Changes and impacts of rental land: For the first time, the land lease in the British Concession of Tianjin adopted the "national lease" method. Since the " Treaty of Nanking" and "Supplementary Treaty" in 1843 determined that foreigners obtained the right of residence in the concession by way of leased land. ${ }^{(8)}$ In the "Land Regulations" of Shanghai in 1845 and 1854 , the method of foreign businessmen renting land directly from the original owners was adopted, that is, "civil rent" in the usual sense, and the permanent rent system was gradually established. The foreign settlements in Japan were initially invested and constructed by the shogunate, so the renters directly paid the rent to the Japanese government. ${ }^{(9)}$ In 1858, the Japanese government privately changed the port of opening from Kanagawa to Yokohama, and started construction activities. ${ }^{(10)}$ In less than a year, the land in Yokohama was occupied by the first foreign merchants, and the supply of land was in short supply. Sir Rutherford Alcock, the Minister in Japan, tries to manage land ownership. ${ }^{(11)}$ In the fifth year after the opening of the port (1863), the number of land in the settlement was officially divided, and the land allocation plan was re-established.

After operating in Shanghai and Japan's concessions, the British government learned from the governance experience of Indian colonies in order to avoid the troubles of landlords bidding up land prices and refusing to lease land when renting the land. ${ }^{(12)}$ Not only regards its territory as the national land represented by the King of England, but also implements the land ownership system of the country represented by the King of England in the colonies occupied by it (Zhengshu C., 1996) in December 1860, Bruce envoy to Prince Gong Yi submit a note (Archives Department of Tianjin Archives, Nankai University Branch Campus., 1992), to manage concessions in China to take "national rent" approach, That is, the British Majesty is directly authorized to rent a whole piece of land to the Chinese government as a special rental, and then the British Majesty will re-allocate the land to the British businessmen. In addition, the

(8) "The Chinese magistrate must discuss with the British governor on the local people's conditions, the place, the house or the base to be used, and the rent shall be for the quasi-British people; the rental price must be based on the current value of the five people, so as to ensure peace. Yun." For details, see Wang Tieya: "Compilation of Chinese and Foreign Old Testament Chapters", Volume 1, Sanlian Bookstore, 1957, reprinted in 1982, p. 35

(9) For details, please refer to the "Land Regulations port of Yokohama" and the sixth paragraph of the "Land Regulations port of Nagasaki ". The historical materials are all from the historical diplomatic materials of the Japanese Ministry of Foreign Affairs.

(10) See Harper \& brothers. The Capital of the Tycoon: A Narrative of a Three Years' Residence in Japan [M], University of Michigan, 1863, VOL1, p137

(11) See: Minutes of a Meeting of British Residents at Yokohama, on February 19, 1861, convened by Her Majesty's Acting Consul, for the purpose of taking into consideration a Report and the proceedings of a preliminary Meeting on the subject of existing grievances and obstructions at this port. Capt. F. Howard Vise, H. B. M. Consul, in the Chair.

(12) In 1858 , Britain directly occupied the India by launching a series of wars against Indian Sikh tribes and the Marata state. In November 1858, Queen Victoria issued a document: "I hereby decide to take over...India as... the territory that I have now..." For details, please refer to Jiang Xiangze: "Selected Materials on the World General History", pages 85, 382-383.
British government is usually not a permanent right to use the land given to foreign investors, according to the Special Committee in 1857, the Bank of England's "Annual Report", the land lease period in most parts of the West, mostly 99 years. Foreign concession lease period for the same 99 years. This is similar to the actual operation of the British and Western real estate markets at that time. The original intention was that the British government could profit from the appreciation of land prices during the turnover of leasehold rights (Marx, Engels., 1972).

"National Rent" forms make the land ownership of the rental in the British government. It strengthens the British government's control over the operation and construction of the land in the concession. The British government was able to take the method of auction and sublet the land in the concession to various foreign firms and merchants, turning the land from feudalowned real estate into freely tradeable urban real estate (Keqiang S., Haiyan L., 1996). The rapid commercialization of land stimulated investment and land development in the concessions. At the same time, after the concession authorities obtained the right of permanent lease, they also developed a master plan for the British concession in Tianjin. In 1861, the Gordon Plan was divided into plots according to the plan (see Figure 2), and the city had overall control.

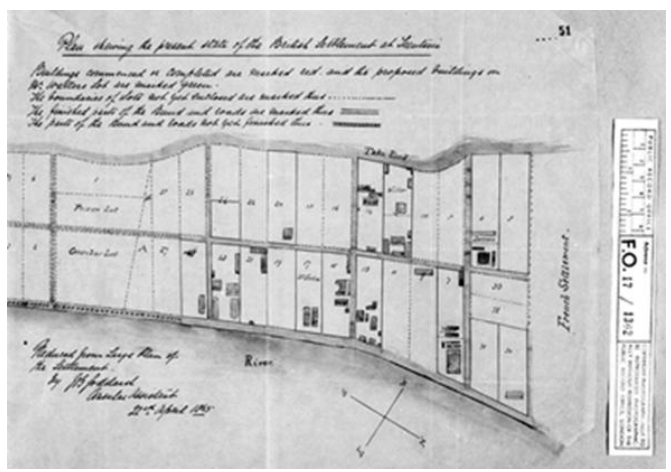

Figure 2. Map of the land parcels in the British Concession of Tianjin in 1865 (Source: British National Archives FO17/1302 ) 
6.2.2 Change and impact of construction management methods: Tianjin British Concession legislated for the first time to recognize the Municipal Council and the concession annual general meeting of electors. In the establishment of "land regulations" before, the British concessions and British people in China and Japan had been trying to obtain the autonomy of the concessions: in the development of the concessions in China, in 1845, the Shanghai "Land Regulations" formed the Committee of Roads and Jetties responsible for collecting and constructing piers, roads, the cost of the bridges. "Land Regulation" in 1854 there had been administrative agencies Municipal Council. In 1855, under the pressure of the British government, Alcock gave up the recognition of the "Municipal Committee" of the concession. Although the meeting of land renters in Shanghai did not agree to dissolve it, its existence has never been supported by any legal documents. Although Japan's Yokohama and Nagasaki settlement there is a bit different from the Shanghai British concession, there are still the administrative characteristics of the settlement: the security and defense rights are dominated by foreigners. Whether it's the renter' $s$ meeting or the Municipal Council = Municipal Committee $=$ Municipal Government, or Streets, Lighting, Coastal Roads and Bund Jetties, the police, Nuisances, Cargoboats and other committees have all created opportunities for the reform of settlement administration for the purpose of strengthening autonomous organizations (Oto Y., 1970). This further clarified the rules and administrative system of concession autonomy on the basis of Shanghai's 1854 "land regulations". But in 1865 , due to financial problems, the Residents ' Corps had to return the management power to the Japanese government.

There are 23 paragraphs in the 1866 "Land Regulations" of the British Concession in Tianjin (Godfrey E.P. Hertslet, ed., 1908), 11 of which are directly related to the autonomy and administrative management of the concession, which accounts for one-half of the entire regulation. It can be divided into two categories, including the establishment of urban management agencies (paragraphs $4,7,8,12,13,14$ ) and related rights of administrative agencies (paragraphs $8,9,10,11,15$ ). The regulation for the first time formed a systematic British Concession Autonomous System, that is, under the electoral registration and publicity system, through the convening of the annual general meeting of electors of the British municipal area in Tientsin, the executive committee of the Tianjin British Concession was established. The executive committee is responsible for revising of the charter of the concession, hiring a staff of the Ministry of Industry, buying and selling public property, collecting taxes, operating public equipment, etc (Masuda T., 1980). This is the first time that the concession has recognized the existence of the Municipal Council in the form of law, and the self-government model of the concession has been formally formed since then.

As a result, urban management and control under the autonomy of the concession have been formed. The regulations related to urban construction in the charter mainly include defining the scope of construction (paragraphs 1,5), clarifying the planning of road-based public land (paragraph 5), Emphasize public safety (paragraphs 17, 18), and functional zoning of land use (including storage area (paragraph 19) and transportation land (paragraphs 20). On this basis, the regulation emphasized the source of funds for municipal activities. In addition to housing donations and land taxes, it also gives the committee of land renters the right to pursue fines. This part of the fine will be used for the municipal construction of the concession (paragraph 21). At the same time, the various costs for construction will be disclosed in advance each year to protect the private property rights of the people in Tianjin. This is a subject of urban planning. Tenant pays rent to the Majesty government (with the auctioneer-style leased to the highest bidder). The lessee needs to fulfill various obligations, including undertaking various fees levied by the committee of land renters for laying drainage facilities, repairing roads or decorating street lights for the concession, building public entertainment venues, and setting up police agencies.

\section{DISCUSSION}

In order to find the relevance of the urban management system of the British concession in East Asia and the similarity of the process of modernization of East Asian cities, and to explore the guiding experience of urban management policies, it is necessary to explore the motivation of the formulation of the regulations. Generally speaking, the formulation of land policy stems from the changes and development of social, political, economic and other factors. In the study of cities and architecture, the famous cultural anthropologist Lapub emphasized in the book "Humanistic Aspects of Urban Form", The essence of the urban physical environment lies in the organization of the space, rather than the material aspects such as the shape and materials of the surface. Culture, system, psychology, etiquette, religious beliefs and lifestyle play an important role in this. If we want to explore the reasons for the formation of the urban space in the concession, we must have the continuity of the urban culture, and renew the research method of cultural ecology from the social, institutional, and cultural aspects. ${ }^{(13)}$ By studying the formation of systems and regulations, besides the social background of the concession at that time, the fundamental reason for the formation of the space is further confirmed. (Figure 3).

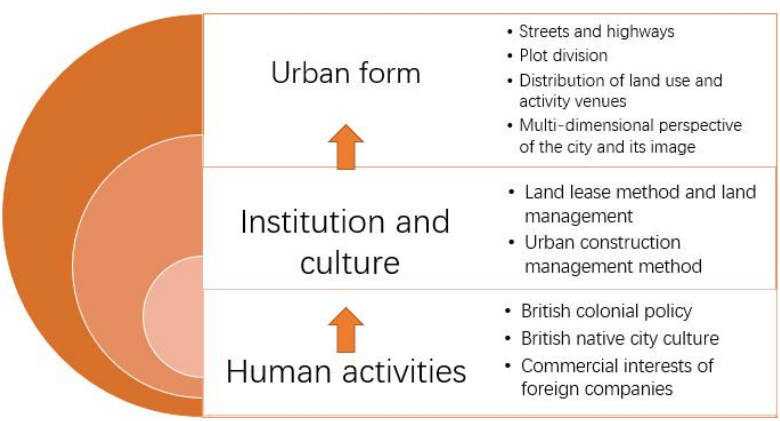

Figure 3. Formation structure of concession space from the perspective of cultural ecology (source: self-painted)

\subsection{The adjustment of British foreign policy towards China}

The change in British foreign policy in 1865 led to a change in the official Chinese attitude towards the autonomy of the concession, which largely affected the urban construction system in the concession. Britain has experienced European

(13) Cultural Ecology is a new type of discipline developed with scientism and humanism from separation, confrontation to integration in the mid-20th century. It was first proposed by American scholar Juliar Haynes Steward in "Theory of Culture Change": Cultural ecology mainly studies the interaction between culture and environment, and has the advantages of interdisciplinary research. Emphasize that the interaction between humans and nature depends on the cultural environment 
Mercantilism from the 17th to the 18th centuries. After the independence of North America in 1783, the First Empire disintegrated, and the New Empire Second Empire was established in 1815. It began to grant its representative government to the white colonies and changed the previous plundering policy. After the second half of the 18th century, the British Empire policy by Adam Smith's colonial theory influence, began to expand trade around the world, from the Americas to the East (Jiahong G., 2007). In the early 19th century, with the abolition of the Corn Law in 1846 and the Navigation Regulations in 1849 , a period of free trade began. During this period, the Little England, represented by the Manchester School, emphasizing respect for colonial sovereignty and the principles of liberalism, efficiency, and peaceful diplomacy was also formed. It reached its peak between 1860 and 1870 (Ying Z., 2014). In this context, Bruce, the British Minister to China, submitted an important memorandum to the British Parliament in 1858, emphasizing the main idea of the Minister in Beijing: respect for the sovereignty and integrity of China's empire (FO 17/306). Britain's friendly attitude towards China enabled the Qing government to support the autonomy and construction of the British concessions at that time. In the meeting of land renters of the Hong Kew Concession held by the U.S. Consulate in Shanghai on September 21, 1863, the U.S. Consul in Shanghai announced the opening of the meeting and announced the settlement agreement he reached with the Chinese local authorities and emphasized:

"It was of importance, as it was the only basis upon which the municipal body which the meeting might create could claim any territorial powers ." (FO 228/412).

In addition, in March 1865, the Windsor Court in Hong Kong passed a new act aimed at better effective judicial management of the British living in China and Japan (Hornby E., 1885). According to the requirements of the act, the Supreme Court of China and Japan named by the Majesty of England will be established in Shanghai to replace the Supreme Court of the United Kingdom in Hong Kong, and the Chief Justice will be directly appointed by the Majesty of England. In 1865, Edmund Grimani Hornby was appointed Chief Judge of the Supreme Court of China and Japan in Shanghai. Hornby supports concession autonomy and participated in the drafting of Shanghai 1869 land regulations. ${ }^{(14)} \mathrm{He}$ believed that for British nationals in the concession, according to Article 85 of the Hong Kong Document of 1865, the authority of the land regulations should come from the Minister in China, and the rights of the Minister in China were obtained by the Privy Council Order of 1853, which is the land regulations. The power ultimately comes from the British Parliament. The minister in China can amend the constitution for the purpose of safeguarding the British government (Robert L. Jarman., 2008), just as Alcock first emphasized in the preface of the land constitution of the British Concession in Tianjin in 1866:

"Her Majesty's Minister in China may from time to time make such Regulations as seem fit for the peace, order, and good government of British subjects resident in or resorting to China, ... and may by any such Regulations repeal or alter any

(14) In the minutes of the Shanghai land renters meeting in 1865 , the Tenant Chairman mentioned that "In terms of himself, he did far less than Judge Hornby, because the judge paid a lot for the amendment. Labor." See the United States. Department of State, Papers Relating to Foreign Affairs, Department of State publication. US Government Printing Office, 1868 vol1, pp429 for details.
Regulations made for any such purpose as aforesaid before the commencement of this Order."(FO371/34)

The right to manage local affairs in the central government emphasizes the necessity of central and government management, which is similar to the way of urban governance in the UK at that time. This also indirectly recognizes that the rights of the Municipal Council are granted by the British government.

"...in which the sources and extent of the powers vested in them should appear clothed in legal phraseology, and in that completeness of form which should characterize every perfect system of self-government..."(15)

\subsection{British urban governance reform}

The 19th century was a period of change in urban governance in the UK. After the first industrial revolution in Britain, the social structure has undergone tremendous changes. Population, industry and commerce have gathered in cities and towns, and the process of urbanization has accelerated. Between 1811 and 1861, the scale of urbanization in Britain has achieved unprecedented development (Weifang L., 1998). The middle class continues to increase. Due to the pursuit of political status by the upper middle class, urban management has gradually moved towards democracy, evolving from urban oligarchy to elected municipal organs. Through the parliamentary reform in 1832, the middle class began to take advantage of the parliament. As far as the jurisdiction of urban governance is concerned, the Urban Self-Government Act of 1835 is largely symbolic, emphasizing the formation of a city government through elections, which is composed of the city council, the mayor and the city council. Corresponding to the British concession are land renters' meeting, chairman of the board, and the committee of land renters.

In 1848, the United Kingdom issued the first "Public Health Act" in response to various urban diseases that emerged after the Industrial Revolution, placing public health under state supervision, creating a precedent for the central government to intervene in local affairs and solve urban problems. It first advocated the establishment of a central sanitation committee to carry out the necessary cleaning, paving, sewage and water supply work. However, the legislation at that time was not mandatory, but was implemented voluntarily by local authorities. Until 1850 , the term municipal utility began to appear. In 1855, the Metropolitan Engineering Bureau was elected to improve the capital's infrastructure. It was in the $1860 \mathrm{~s}$ that the focus of the British government shifted to municipal administration, and the quality and quantity of municipal activities changed significantly.

\subsection{Influence of important people}

The implementation of the policies of foreign powers often requires specific historical opportunities or the advancement of important figures. After the First Opium War in 1842, Britain and China reached the "Five-Port Treaty of Commerce" for the first time. At this time, the British colonial relationship with China was experimental, so that the consuls appointed to these five ports were hurriedly selected without special training.

${ }^{(15)}$ The United States. Department of State, Papers Relating to Foreign Affairs, Department of State publication. U.S. Government Printing Office, 1868 vol1, 431 
Because the early consuls were far away from the British government, they mainly relied on their own resources to manage the concessions, and their personal consciousness had a greater impact on the management of the concessions and the advancement of the colony (Michie A., 1900), Rutherford Alcock (1807 1897) $)^{(16)}$ is one of them (Figure 3). After the signing of the Treaty of Tianjin in 1858 and the Treaty of Beijing in 1860, Britain made further demands on the diplomatic, consular and judicial affairs of East Asia. Chinese consuls began to be regarded as special occupations, and entry into the post required relevant examinations. At the same time, by absorbing the experience of the first batch of managers, the United Kingdom began to expand the concessions throughout East Asia, which also made the construction of East Asian concessions and settlements have certain rules and similarities.:

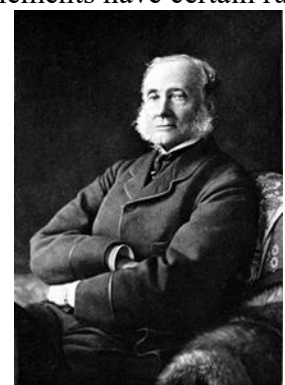

Figure 3. Alcock (Rutherford Alcock, 1807 1897) (Source: The Michie of The Englishman in China During A. The Victorian Era: of As in The Illustrated Career of Sir Rutherford Alcock, W. Blackwood \& Sons, 1900. Vol1. Flyleaf )

In 1864, Bruce left the post of British Minister to China and was replaced by Alcock, who has always had his ideas about the autonomy of the concessions. As early as when he was the consul of Shanghai, he showed his strong ideological attitude towards British rule in East Asia. Such as maintenance, committed to increasing British consul controls on Concession, using Article 10 of the Shanghai "Land Regulations" in 1854 as a breakthrough point to encourage foreign tenants to establish a "Shanghai Municipal Committee", which gave birth to the Municipal Council and accelerated the process of colonization of Shanghai' $s$ foreign concessions. Academia has already conducted in-depth research on it. ${ }^{(17)}$ When serving as the Minister in Japan for the management of British people, he pointed out that while local autonomy was emphasized, some rules must be clarified to ensure the peace of foreign communities (Harper \& brothers., 1863):

"Democracy means freedom...Law is a necessary condition for freedom...Justice must be carried out by some organized power..." (Harper \& brothers., 1863)

He also made it clear that European policies are more advanced, and that the people's democratic autonomy system is needed in

(16) Alcock served as consul in Fuzhou in 1844, and temporarily served as consul in Xiamen for several months on the way to the post. During his tenure in Xiamen, he had a great influence on the location of the consulate. In August 1846, he served as the consul in Shanghai. In 1854, he was transferred to the consul of Guangdong. In 1859, he became the consul general of the United Kingdom in Japan.

(17) For example, Ye Bin. Internationalization and Colonization of Shanghai Concession: A Brief Discussion on "1854 Land Regulations" [J]. Shi Lin, 2015, 3. Lu Hanchao. Research on "Shanghai Land Regulations" [A]. an advanced culture (Masuda T., 1980). His exploration of the management of Japanese settlements was groundbreaking. He successively promulgated a series of inherited "Land Regulations" in Yokohama, Nagasaki, Kobe and other places. He also signed the "Yokohama Settlement Letters" at the same time. Provisions are made for foreigners to manage the land tax on their own. Although his attempt in Japan ended in failure ${ }^{(18)}$, with his previous management experience in the Sino-Japanese concession, he held greater ambitions as the minister in China. The tenants in the Shanghai concession gained the hope of increasing the power of municipal management and began to re-formulate the land regulations (United States., 1868).

Renters in Shanghai have tried to amend the land regulations since 1863. After Alcock appointment, all revisions have been confirmed with him (Figure 5). ${ }^{(19)}$ In July 1866, the Tenant's Conference passed a newly revised draft. Winchester resubmitted to Alcock audit, Alcock reply on November 15 . He emphasized the necessity of amending the land regulations, clarifying that the objectives of this amendment are:

"The adoption of a practical scheme of municipal government for one of the largest and most important cosmopolitan settlements in the east"

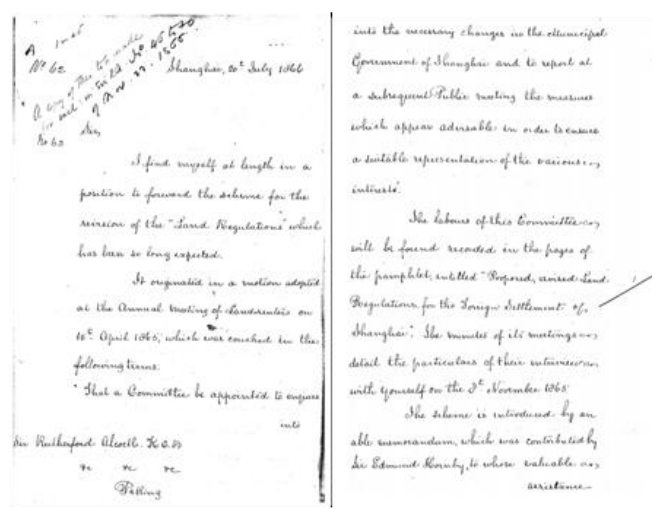

Figure 5. Correspondence between Arleigh and Winchester (Source: THE NATIONAL ARCHIVIES, FO228/412.)

Although it may not be exactly the same as similar institutions in the UK and have a more complete system, it must ensure effective control of the municipality. Secondly, Alcock emphasized the authority of this municipal organization:

"the chief objects of municipal government were intended to be provided for, and in the calling together of the land renters to declare an assessment and impose dues, and the appointment of an executive committee to levy and apply the funds raised, the essential forms of municipal government were adhered to "

Emphasize that this is a matter of principle, and mention:

"...the inability complained of by successive municipal administrations to give effect to the votes of the land 'renters

(18) In 1866 , due to the financial crisis, the management of the Yokohama settlement was returned to the shogunate during the Doryya Fire Incident 1866. The municipal funding for the Yokohama settlement was provided by the Kanagawa local government from beginning to end. This was also destined for the Yokohama settlement. The diaspora cannot be fully autonomous.

(19) which in February 1866, Winchester to Alcock letters about amending the land regulations, reported in April to discuss the memorandum of land renters' meeting and in July reported on the progress of the amend of land regulations again, $\mathrm{FO} 228 / 412,413$ 
and the most necessary measures for the peace, order and sanitary state of the settlement..." (FO 228/413).

Finally, Alcock proposed the most important step for passing these resolutions, which is best to use the official approval of the Land Regulations as the legal basis (FO 228/413). On November 26, which is 11 days later, Alcock took the lead in promulgating Tianjin's Land Regulations, which were similar in content to the third land regulations submitted by Shanghai to Alcock in 1866. Tianjin's 1866 land charter is the first attempt by Alcock to directly apply his experience in the management of the Sino-Japanese concession to the British concession. It directly refers to the third land charter of Shanghai in 1866.

\section{CONCLUSION}

Tianjin's 1866 land regulations was affected by the adjustment of the British dialogue foreign policy, and were closely related to the transformation of British urban governance. Especially, it was inseparable from the key role played by Alcock, who had served as consul and minister in China and Japan. The experience in the management of the Sino-Japanese concession was directly applied to the first attempt to manage the British concession. It was directly affected by the construction management system of Shanghai and Japanese foreign settlements. It has an important influence on the construction management system of other foreign concessions in Tianjin and the management system of the British concessions and settlements in East Asia

This article analyses the historical process of the formulation of Tianjin's 1866 land regulations. It explores the relevance of the management system of the British concessions in East Asia and the similarity of the process of modernization of East Asian cities. The construction management system of the concession period has played an important reference role for Shanghai, Tianjin, Yokohama, Nagasaki and subsequent urban construction. It is an inseparable part of the history of urban planning. Throughout the development process of the "Land Regulations" in the East Asian British Concession, the formulation of its management model mainly experienced the following stages: 1. The upper-level policy's guidance and control of the overall direction; 2 . The optimization of the organizational framework and operation mode; 3. Establish and improve laws and regulations to legalize them; 4. Clarify the main body of the plan, and the people will participate in the formulation process.

\section{ACKNOWLEDGEMENTS}

This research was funded by the National Natural Science Foundation of China "Comparative Study on the Planning and Construction of Modern British Concessions and Settlements in East Asia" (51878438), and Tianjin Natural Science Foundation "The Construction and Application of Tianjin Cultural Heritage Smart Guide Information Database" (18JCYBJC22400).

\section{REFERENCES}

Archives Department of Tianjin Archives, Nankai University Branch Campus., 1992: Selected Archives of Tianjin Concession, Tianjin People's Publishing House, 5-6.

Bentao W., 2009: A brief analysis of the British "Little England" in the mid-19th century. Journal of Capital Normal University (Social Science Edition) (06), 28-32.
Benying Z., 2009: The establishment of the free empire 18151870 The history of the British Empire. Anhui University Press. Chengkang F., 1991: History of Chinese Concession. Shanghai Academy of Social Sciences Press.

Godfrey E.P. Hertslet, ed., 1908: Hertslet's China Treaties "Local Land Regulations of the British Concession of Tientsin and General Regulations for the Tientsin Consular District ( Peking, 26th November, 1866 ), London: Harrison and Sons, $637-639$.

Harper \& brothers., 1863: The Capital of the Ty-coon: A Narrative of a Three Years' Residence in Japan, University of Michigan, VOL1, 316.

Hornby E., 1885: Instructions to Her Majesty's Consular Officers in China and Japan, on the Mode of Conducting Judicial Business: With Comments on the China and Japan Order in Council, 1865, and the Rules of Procedure Framed Under it. Kelly \& Walsh, Limited.

Jiahong G., 2007: From the Old Empire to the New Empire History of the British Empire 1783-1815. The Commercial Press.

Keqiang S., Haiyan L., 1996: Social Research in Tianjin Concession. Tianjin: Tianjin People's Publishing House.

Keyan G., 2014: Space, System and Society: A Study of the British Concession in Tianjin in Modern Times (1860-1945). Nankai University, $\mathrm{PhD}$ dissertation.

Marx, Engels., 1972: Selected Works of Marx and Engels: Volume 24. People's Publishing House. 235, 394.

Masuda T., 1980: British in the late Tokugawa periodRutherford Alcock. Kobe University Research Sosho Publishing Association.

Michie A., 1900: The Englishman in China during the Victorian era: As illustrated in the career of Sir Rutherford Alcock. W. Blackwood \& sons, vol2, 354.

Oto Y., 1970: A Study on the Yokohama Settlement in the First Year of Man'en. Kanagawa Prefectural Museum Research Report, No. 3.

Robert L. Jarman., 2008: Shanghai: political and economic reports, 1842-1943: British government records from the international city. Archive Editions.

Shengcai S., Shuai H., 2020: Problems in China's urban planning management. Urban construction theory research (electronic version) (14), 16.

THE NATIONAL ARCHIVES, FO 17/306. Memorandum by Frederick Bruce on the new arrangements in China, dated London, 21 October 1858.

\section{THE NATIONAL ARCHIVES, FO228/412.}

\section{THE NATIONAL ARCHIVES, FO228/413.}

United States., 1868: Department of State, Papers Relating to Foreign Affairs, Department of State publication. U.S. Government Printing Office, voll, 430. 
The International Archives of the Photogrammetry, Remote Sensing and Spatial Information Sciences, Volume XLVI-M-1-2021 28th CIPA Symposium “Great Learning \& Digital Emotion”, 28 August-1 September 2021, Beijing, China

Weifang L., 1998: The characteristics of modern British urbanization and its social influence. Journal of Nantong Teachers College (Social Science Edition) (01).

Ying Z., 2014. Urban planning regulations and construction implementation during the Hankou Concession Period. Tsinghua University, MA thesis.

Zhengshu C., 1996: Research on the origin of the permanent rent system of urban land in modern Shanghai. Shi Lin (02) 